\title{
Adaptation of the Person-Centered Maternity Care scale for people of color in the United States
}

\section{Authors:}

Patience A. Afulani, PhD, MBChB ${ }^{\mathrm{a}, \mathrm{b}}$, Molly R. Altman, PhD, $\mathrm{CNM}^{\mathrm{c}}$, Esperanza Castillo, $\mathrm{MS}^{\mathrm{b}, \mathrm{d}}$, Nayeli Bernal, MPH ${ }^{d}$, Linda Jones ${ }^{d}$, Tanefer Camara MHA ${ }^{d}$, Zoe Carrasco, RN $^{d}$, Shanell Williams $^{\mathrm{b}, \mathrm{d}}$, May Sudhinaraset PhD, ${ }^{\mathrm{e}}$, Miriam Kuppermann, PhD, MPH ${ }^{\mathrm{a}, \mathrm{b}, \mathrm{d}}$.

${ }^{\text {a }}$ Department of Epidemiology and Biostatistics, University of California

${ }^{\mathrm{b}}$ Department of Obstetrics, Gynecology, \& Reproductive Sciences, University of California, San Francisco

${ }^{\mathrm{c}}$ Department of Child, Family, and Population Health Nursing, University of Washington

${ }^{d}$ California Preterm Birth Initiative, University of California, San Francisco

${ }^{\mathrm{e}}$ Department of Community Health Science, University of California, Los Angeles

Corresponding author: Patience Afulani, PhD, MPH, MBChB, Department of Epidemiology and Biostatistics, University of California, San Francisco, 550 16th St, San Francisco, CA 94158,

\section{Patience.Afulani@ucsf.edu}

Funding Statement: This work was supported in part by the University of California, San

Francisco, California Preterm Birth Initiative, funded by Marc and Lynne Benioff. The funder had no role in the study design, data collection, analysis and interpretation of data; in the writing of the report; and in the decision to submit the article for publication. 


\section{Acknowledgements:}

We would like to thank all members of the California Preterm Birth Initiative Community Advisory Board, everyone who provided feedback at various phases of the scale development, and all the people who participated in the numerous stages of the project. We are also grateful to everyone who helped with recruitment and other members of our research team (Nadia Diamond-Smith and Nicholas Rubashkin at the University of California, San Francisco).

Data Access and Responsibility: PA had full access to all the data in the study and takes responsibility for the integrity of the data and the accuracy of the data analysis.

Disclosure Statement: The authors report no conflict of interest.

Keywords: Person-centered care; maternity care, intrapartum care, birth; people of color; Black women; community-based participatory research; respectful maternity care; experience of care; quality of care; measurement 
medRxiv preprint doi: https://doi.org/10.1101/2021.05.06.21256758; this version posted May 10, 2021. The copyright holder for this preprint (which was not certified by peer review) is the author/funder, who has granted medRxiv a license to display the preprint in perpetuity. It is made available under a CC-BY-NC 4.0 International license.

\begin{abstract}
Introduction: Mistreatment by healthcare providers disproportionately affects people of color in the United States (US). The goal of this study is to adapt the global Person-Centered Maternity Care (PCMC) scale to the experiences of people of color in the US using a communityengaged approach.
\end{abstract}

Methods: We conducted expert reviews to improve content validity and cognitive interviews with potential respondents were conducted to assess relevance, comprehension, and comprehensiveness. Surveys of 297 postpartum people, $82 \%$ of whom identified as Black, were used for psychometric analysis in which we assessed construct and criterion validity and reliability. The University of California, San Francisco, California Preterm Birth Initiative's Community Advisory Board (CAB), which consists of community members, community-based health workers, and social service providers in Northern California, provided input during all stages of the project.

Results: Through an iterative process of factor analysis, discussions with the CAB, and a prioritization survey, we eliminated items that performed poorly in psychometric analysis, yielding a 35-item PCMC-US scale with sub-scales for "dignity and respect," "communication and autonomy," and "responsive and supportive care." The Cronbach's alpha for the full scale is 0.95 and for the sub-scales is 0.87 . Standardized summative scores range from 0 to 100 , with higher scores indicating higher PCMC. Correlations with related measures indicated high criterion validity.

Conclusions: The 35-item PCMC-US scale and its sub-scales have high validity and reliability in a 
medRxiv preprint doi: https://doi.org/10.1101/2021.05.06.21256758; this version posted May 10, 2021. The copyright holder for this preprint (which was not certified by peer review) is the author/funder, who has granted medRxiv a license to display the preprint in perpetuity.

It is made available under a CC-BY-NC 4.0 International license .

sample of predominantly Black women. This scale provides a tool to support efforts to reduce the disparities in birth outcomes among people of color. 
medRxiv preprint doi: https://doi.org/10.1101/2021.05.06.21256758; this version posted May 10, 2021. The copyright holder for this preprint (which was not certified by peer review) is the author/funder, who has granted medRxiv a license to display the preprint in perpetuity. It is made available under a CC-BY-NC 4.0 International license .

\section{INTRODUCTION}

2 Disrespectful care and mistreatment by healthcare providers have been shown to

3 disproportionately affect people of color in the United States (US), particularly Black pregnant

4 and birthing people, and have been attributed to racism and discrimination (Alhusen et al.,

5 2016; Altman et al., 2019; McLemore et al., 2018; Vedam, Stoll, Taiwo, et al., 2019).

Hospitalizations for labor and delivery are often considered the apex for these experiences, not

7 only because birth is a major life transition, but also due to exposure to unfamiliar providers

8 and a culture of care that may or may not be aligned with patient expectations (Lyndon et al.,

$92018)$.

Person-centered care, or care that emphasizes the wants and needs of the patient over

11 the provider, focuses on respect, trust, dignity, support, autonomy, and communication among

12 other domains, and represents a major determinant of high-quality care provision (Institute of

13 Medicine (US) Committee on Quality of Health Care in America, 2001; WHO, 2016). Various

14 aspects of person-centered care during childbirth are affected by implicit bias and are often

15 dependent on providers' assumptions regarding the ability of birthing people to make decisions

16 about their care (Afulani, Ogolla, et al., 2021; Altman et al., 2019; Vedam, Stoll, McRae, et al.,

17 2019).

While numerous qualitative studies have examined aspects of person-centered

maternity care, very few have attempted to operationalize it quantitatively to enable

20 measurement of the effectiveness of interventions aimed at improving quality of care, and, to

21 our knowledge, none have looked at the unique experiences of Black pregnant and birthing

22 people in the US (Nilvér et al., 2017). We sought to adapt and validate a scale to measure 
medRxiv preprint doi: https://doi.org/10.1101/2021.05.06.21256758; this version posted May 10, 2021. The copyright holder for this preprint (which was not certified by peer review) is the author/funder, who has granted medRxiv a license to display the preprint in perpetuity.

It is made available under a CC-BY-NC 4.0 International license .

23 person-centered care during labor and childbirth to reflect the experiences of people of color in

24 the US, with an emphasis on the experiences of Black women and birthing people.

MATERIALS AND METHODS

27 The Person-Centered Maternity Care (PCMC) scale, which was initially developed for use in lowresource countries and has been validated in several contexts (Afulani et al., 2017, 2018; Afulani, Phillips, et al., 2019), served as the basis for this US-focused version. The original PCMC scale was first validated in Kenya and subsequently in India and Ghana (Afulani et al., 2018;

31 Afulani, Phillips, et al., 2019; Afulani, Aborigo, et al., 2019). To adapt this scale for use in the US,

32 we followed standard scale development procedures in addition to a community-engaged

33 approach to ensure that it is valid, reliable, and fits the needs of Black birthing people and

34 families (DeVellis, 2016; Hinkin et al., 1997). Specifically, a literature review was conducted to

35 define the construct and identify domains and to develop the initial list of items (Afulani et al.,

36 2017). We then adapted the scale using expert reviews, cognitive interviews, structured

37 surveys, and psychometric analysis - engaging community members throughout the process-

38 and named the adapted version the PCMC-US scale. We used a parallel process to develop a

39 prenatal care-oriented measure, which we refer to as the Person-Centered Prenatal Care

40 (PCPC) scale (Afulani, Altman, et al., 2021).

41 Expert reviews: The goal of the expert review was to optimize content validity in terms of

42 relevance and comprehensiveness (DeVellis, 2016). Our research team, which included

43 clinicians and researchers, first reviewed the 30 items in the original PCMC scale and removed

44 items not applicable to the US setting (e.g., availability of water and electricity). We then held 
medRxiv preprint doi: https://doi.org/10.1101/2021.05.06.21256758; this version posted May 10, 2021. The copyright holder for this preprint (which was not certified by peer review) is the author/funder, who has granted medRxiv a license to display the preprint in perpetuity. It is made available under a CC-BY-NC 4.0 International license.

an expert review session with 10 members of the University of California, San Francisco (UCSF), includes people of color who have had preterm births, community-based health workers, and social service providers in Northern California. The CAB members represent community experts who understand what PCMC means to people of color because of their direct service and lived experiences in the communities of focus. A second expert review session consisted of 20

51 people, including two community health workers, four CAB members, and 14 faculty members

52 (researchers and clinicians). During these sessions, the remaining questions were reviewed, and several new questions were recommended that related to existing PCMC domains (Examples:

54 "Did you feel heard and listened to?" "Did providers encourage you to ask questions?" "Did providers knock on your room's door and wait for response before entering?"). Questions on infant feeding choices and emotional well-being were also added. CAB members were paid

$57 \$ 40 /$ hour for their participation in these sessions.

58 Cognitive interviews: We next conducted cognitive interviews to assess and improve

59 comprehensibility, relevance, and comprehensiveness of the questions (Collins, 2003; NápolesSpringer et al., 2006). We developed an interview guide that included questions on item

61 wording, possible sources of confusion, and appropriateness of items, as well as whether

62 questions were missing. We then conducted the cognitive interviews with 15 participants who

63 were $\geq 28$ weeks pregnant or had given birth within the past year. Participants were recruited

64 from partner organizations and from a UCSF database of patients who had previously

65 participated in studies and were interested in being contacted for future studies. Participants 
medRxiv preprint doi: https://doi.org/10.1101/2021.05.06.21256758; this version posted May 10, 2021. The copyright holder for this preprint (which was not certified by peer review) is the author/funder, who has granted medRxiv a license to display the preprint in perpetuity.

It is made available under a CC-BY-NC 4.0 International license .

67 revise the items. We had 50 candidate items for the PCMC-US scale (Table 1) at the end of the

68 cognitive interviews. These questions were then integrated into the study questionnaire that

69 included items on sociodemographic characteristics and other issues. The questionnaire was

70 piloted with eight people meeting eligibility criteria for the planned survey to assure

71 acceptability and ease of completion.

72

$73===$ Table 1 Full set of PCMC questions==

74

75 Survey: Participants for the survey were recruited through community-based organizations and

76 targeted social media advertisements. Individuals aged 15 years or older who had given birth in

77 the past year were eligible to participate, and recruitment materials indicated that the study

78 was focused on the experiences of people of color. We conducted the survey between January

79 and September 2020 using the REDCap (Research Electronic Database Capture) online survey

80 platform for data collection (Harris et al., 2009). Individuals who were interested in joining the

81 study emailed the study team, answered eligibility questions, and once confirmed as eligible,

82 were emailed a personalized link to complete the survey. Study information was provided on

83 the landing page and respondents clicked a button to indicate informed consent before the

84 survey opened up. Participants received a $\$ 40$ electronic gift card upon completing the survey.

85 Ethical approval was obtained from UCSF's Institutional Review Board.

86 Psychometric analyses: The goal of the psychometric analyses was to assess and improve

87 construct and criterion validity and internal reliability of the scale (DeVellis, 2016; Hinkin et al.,

88 1997). We examined the distributions of all the items and recoded some response options to 
medRxiv preprint doi: https://doi.org/10.1101/2021.05.06.21256758; this version posted May 10, 2021. The copyright holder for this preprint (which was not certified by peer review) is the author/funder, who has granted medRxiv a license to display the preprint in perpetuity.

It is made available under a CC-BY-NC 4.0 International license.

obtain a uniform scale. To ensure that all response options ranged from 0 to 3 , we recoded items that had a "not applicable" category (4) to the upper middle category (2: most of the time). We also reverse-coded negative items so that all responses reflected a scale ranging from

920 as the lowest level to 3 as the highest level. We then constructed a correlation matrix to 93 examine the correlations among the items. Construct validity was assessed using exploratory factor analysis (DeVellis, 2016; Hinkin et al., 1997). The Kaiser-Meyer-Olkin (KMO) measure was used to test suitability of the items

96 for factor analysis. The decision on how many factors to retain was made using Kaiser's rule of

97 retaining only factors with eigenvalues $\geq 1$, and examining the "elbow" of the scree plot (plot of

98 eigenvalues) (Afifi et al., 2004; DeVellis, 2016; Hinkin et al., 1997). Oblique rotation, which

99 allows for correlation between the rotated factors, was used because the person-centered care domains are theoretically related (Afifi et al., 2004; Hinkin et al., 1997). We used initial criteria

101 of factor loadings $\geq 0.3$ and uniqueness of $\leq 0.8$ in iterative factor analysis, combined with

102 feedback from the CAB to determine which items to retain or exclude (Afifi et al., 2004). Sub-

103 scales were generated using the loading of the items on the extracted factors and conceptual

104 groupings, and the items were summed to generate the PCMC-US scale and sub-scale scores. Internal consistency reliability was assessed using Cronbach's alpha (DeVellis, 2016;

106 Hinkin et al., 1997). To assess criterion validity, we examined whether scales and sub-scales

107 were associated with theoretically related measures (DeVellis, 2016). For example, we

108 hypothesized that the PCMC-US scale would be associated with satisfaction and perceptions of

109 the quality of intrapartum care received, and whether the participant would use the same

110 service in the future (Afulani et al., 2017; Sheferaw et al., 2016). We also examined the 
medRxiv preprint doi: https://doi.org/10.1101/2021.05.06.21256758; this version posted May 10, 2021. The copyright holder for this preprint (which was not certified by peer review) is the author/funder, who has granted medRxiv a license to display the preprint in perpetuity.

It is made available under a CC-BY-NC 4.0 International license .

111 association between the PCMC-US scale and two other measures which assess women's

112 combined experiences during pregnancy and childbirth: the Mothers Autonomy in Decision

113 Making scale (MADM) and the Mothers on Respect Index (MORi) index (Vedam, Stoll, Martin, et

114 al., 2017; Vedam, Stoll, Rubashkin, et al., 2017). We tested our hypotheses through correlations

115 and bivariate linear and logistic regression analysis. STATA version 15 was used for all analyses.

\section{RESULTS}

118 In all, 312 participants completed the study. Fifteen participants who did not respond to all the

119 PCMC-US items were excluded, resulting in an analytic sample of 297. Most respondents

120 identified as Black (82\%). The average age was 29 years old (SD=3.6), and most participants

121 were married (89\%), primiparous (76\%), and college graduates (52\%; Table 2).

123 ====Table 2: Sociodemographic and clinical characteristics==== exceptions, the responses ranged between 0 and 3. The proportion of N/A responses on items

127 that generated N/A responses ranged from 1 to $13 \%$ except for the question regarding whether

128 providers explained medications, for which $54 \%$ responded that they did not receive any

129 medicine. There was good correlation between most items, which generally ranged from 0.2 to

130 0.7. Items that had correlations of $<2$ or negative correlations with other items were flagged.

131 These included the question on preferred name, preferred language, position of choice, being

132 separated from the baby, support for feeding goals, cleanliness, coercion, holding back from 
medRxiv preprint doi: https://doi.org/10.1101/2021.05.06.21256758; this version posted May 10, 2021. The copyright holder for this preprint (which was not certified by peer review) is the author/funder, who has granted medRxiv a license to display the preprint in perpetuity.

It is made available under a CC-BY-NC 4.0 International license .

133 asking questions, and crowding.

The KMO measures of sampling adequacy for all items ranged from 0.69 to 0.97 , with an

135 overall KMO of 0.94 , indicating suitability for factor analysis. The initial factor analysis with all

13650 items yielded 6 factors with eigenvalues of $\geq 1$, accounting for $84 \%$ of the cumulative

137 variance. However, there was one dominant factor (Figure 1) with an eigenvalue of 16.8, which

138 accounted for $60 \%$ of cumulative variance. The eigenvalues for the other factors were $<2$

139 (range: 1.0 to 1.6). All the items had a factor loading of $\geq 0.3$ on at least one of the 6 factors

140 except the questions on introduction, language, informed about what was happening, and

141 support for feeding goals, which had loadings of between 0.2 and 0.3 . Uniqueness for all items

142 was $<0.8$ except for introduction, separation, language, holding back from asking questions, and

143 crowding, which had uniqueness between 0.8 and 0.9 . When the analysis was restricted to the

144 single factor structure, all items had loadings of $>0.3$ except the items on name, separation,

145 explained medications, coercion, holding back from asking questions, and crowding, which had

146 loadings of $<0.2$ and uniqueness $>0.9$. We conducted iterative factor analysis dropping different

147 items and examining the results. Given the need for a parsimonious scale, we also identified

148 items that were conceptually similar for possible elimination.

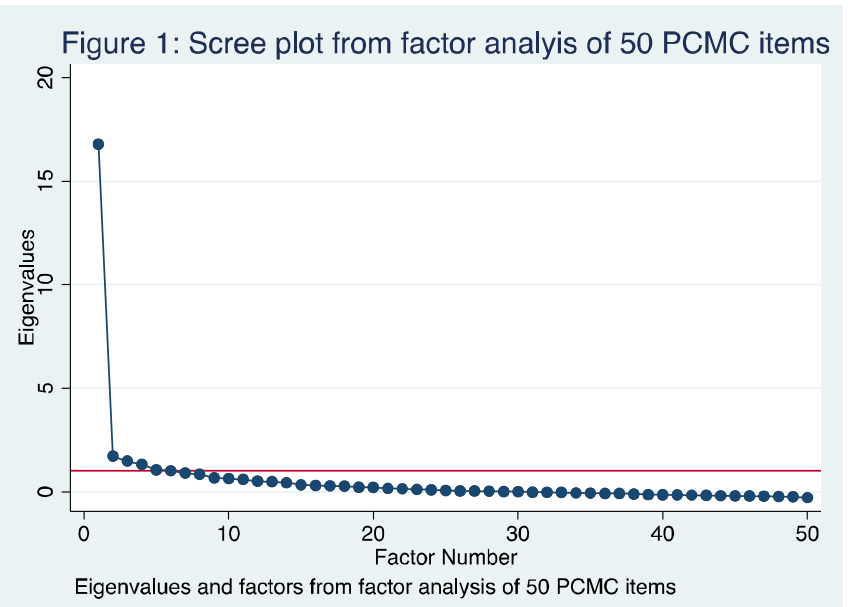


medRxiv preprint doi: https://doi.org/10.1101/2021.05.06.21256758; this version posted May 10, 2021. The copyright holder for this preprint (which was not certified by peer review) is the author/funder, who has granted medRxiv a license to display the preprint in perpetuity. It is made available under a CC-BY-NC 4.0 International license.

We presented the initial findings to the $C A B$ and suggested dropping the items that had

151 low loadings, high uniqueness, or conceptual difference/similarity. Although some CAB

152 members acknowledged 50 items were too many for a scale, many strongly felt that all

153 questions were important and should be included, so we could not achieve consensus on items

154 to drop. Thus, to enable us to get to a smaller subset of questions, we used the results of the

155 factor analysis, as well as conceptual domains based on the World Health Organization

156 experience of care domains (Tunçalp et al., 2015), to group the 50 items into three domains for

157 "Dignity and Respect" (DR: 11 items), "Communication and Autonomy" (CA: 19 items), and

158 "Responsive and Supportive Care" (RS: 20 items) We then created a survey, grouping

159 conceptually similar items together, and asked CAB members as well as research team

160 members to select their top 8 to 10 questions from each domain.

163 items selected by less than a third of respondents $(<5)$, as this suggested low priority, resulting

164 in the elimination of 13 items ( 4 from CA, 1 from DR, and 8 from RS). We then re-ran the factor

165 analysis on the remaining 37 items. All but three items had loadings $>0.3$ on the single factor for

166 each domain and on the full scale (coercion, called by preferred name, and being separated

167 from baby). Since the items on preferred name and being separated from baby were not highly

168 ranked in the survey (selected by only 5 people), we decided to drop these two items next, but

169 retained the coercion item despite its low loading because it was recommended by most

170 respondents (9) and was one of the items CAB members felt strongly about retaining. Of note,

171 despite reporting a generally good experience, about $30 \%$ of participants in this sample 
medRxiv preprint doi: https://doi.org/10.1101/2021.05.06.21256758; this version posted May 10, 2021. The copyright holder for this preprint (which was not certified by peer review) is the author/funder, who has granted medRxiv a license to display the preprint in perpetuity.

It is made available under a CC-BY-NC 4.0 International license .

172 reported being pressured into a decision by their providers, pointing to the importance of this

173 item. This yielded a 35-item scale with 3 factors (Figure 2). All items had loadings $>0.3$ on the

174 full scale and on the single factor for each domain, except the item on coercion (Table 3).

175 Dropping the coercion item yielded a 34-item version in which all had loadings $>0.3$ on the full

176 scale and on the single factor for each domain. Inclusion of the coercion item, however, did not

177 significantly change the loadings of the other items or the Cronbach's alpha (which was 0.95 in

178 both cases). So the 35-item version was maintained with 14, 10, and 11 items respectively for

179 the CA, DR, and RS sub-scales. The Cronbach's alpha for all the sub-scales is 0.87 (Table 4).

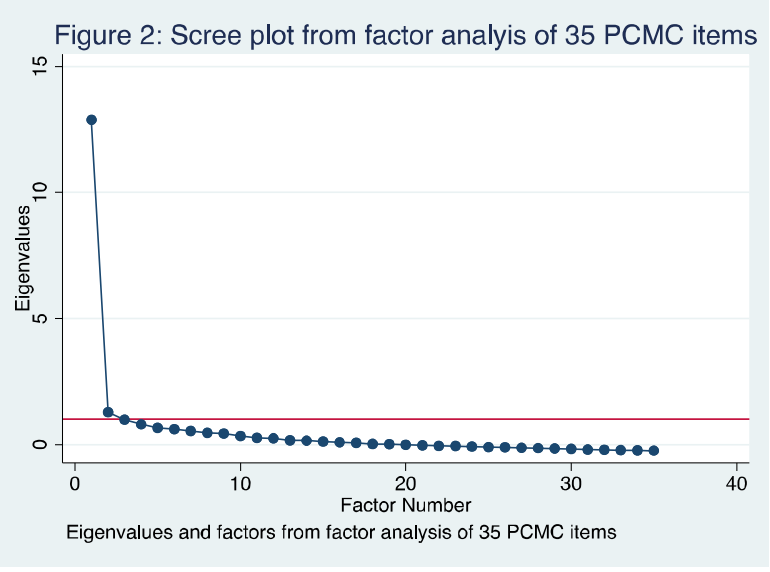

$181====$ Table 3 Factor analysis results====

182

To create summative scores for the full scale and sub-scales, the responses on the items

183 for each are added. These scores are then standardized by dividing the mean score by the

184 maximum possible scores ((e.g., $105\left(35^{*} 3\right)$ for full scale, $42\left(14^{*} 3\right)$ for $C A, 30(10 * 3)$ for $D R$, and

$18533\left(11^{*} 3\right)$ for RS)) and multiplying by 100 . The standardized scores thus range from 0 to 100 for

186 all the scores, where 0 is the worst PCMC and 100 is the best PCMC one can receive. The raw

187 and standardized scores are shown in Table 4. The results show an average standardized PCMC

188 score of 89. The highest sub-scale score is for Dignity and Respect (92) and the lowest score is 
medRxiv preprint doi: https://doi.org/10.1101/2021.05.06.21256758; this version posted May 10, 2021. The copyright holder for this preprint (which was not certified by peer review) is the author/funder, who has granted medRxiv a license to display the preprint in perpetuity.

189 for Communication and Autonomy (87).

190 ===Table 4: Scale Properties===

191 The associations between the full PCMC-US scale and sub-scales and the related

192 measures provided support for criterion validity. The regression of each of the sub-scales and

193 the full scale on participants' ratings of satisfaction with services, general quality ratings, and

194 whether they would give birth in the same facility if they were to become pregnant again shows

195 increasing PCMC is associated with higher odds of satisfaction and quality of care and intent to

196 give birth in the same facility in the future (Table 5). The correlation coefficients between the

197 PCMC-US scale and sub-scale scores and the MORi and MADM scale scores are all >0.5, with a

198 correlation coefficient of 0.69 for CA and MADM and 0.63 for DR and MORi.

199

$200===$ Table $5:$ Criterion validity results ===

201

202

DISCUSSION

203 We used a rigorous, community-engaged approach to adapt the Person-Centered Maternity

204 Care scale to reflect the experiences of people of color in the US. Through expert reviews and

205 cognitive interviews, we developed 50-items that capture person-centered maternity care for

206 women of color. We then used psychometric analysis and feedback from the CAB to reduce the

207 items to a 35-item PCMC-US scale, which has three sub-scales measuring dignity and respect,

208 communication and autonomy, and responsive and supportive care. The full scale and the sub-

209 scales have good content, construct, and criterion validity with Cronbach's alphas of 0.95 for

210 the main scale and $>0.8$ for the sub-scales. 
medRxiv preprint doi: https://doi.org/10.1101/2021.05.06.21256758; this version posted May 10, 2021. The copyright holder for this preprint (which was not certified by peer review) is the author/funder, who has granted medRxiv a license to display the preprint in perpetuity. It is made available under a CC-BY-NC 4.0 International license.

211 The final version of the PCMC-US scale ended up being similar to the original version

212 (Afulani et al., 2017, 2018), with some subtle differences. Both versions have similar sub-scales,

213 given the similar set of items and conceptual groupings using the WHO experience of care

214 domains (Tunçalp et al., 2015). Although the wording of the questions resemble the original

215 questions, the adaption process ensured that the exact wording of items in the new version are

216 appropriate for the US context. The response options used in the original PCMC scale were

217 maintained, as participants in the cognitive interviews found the frequency response format to

218 be easy to respond to and did not think it should be changed. This response format leads to

219 more variability in responses than binary yes/no responses. Acquiescence bias is also less of an

220 issue than the agree/disagree format used in other scales (Holbrook, 2008).

221 The original PCMC scale has 30 items, compared to 35 items in the PCMC-US scale. This is

222 due to several questions that were added during the adaptation process, leading to a set of 50

223 potential items, all of which were felt to be highly relevant by the cognitive interview

224 participants and the CAB. The 35 items included in the PCMC-US scale are the result of our

225 attempt to produce a parsimonious but comprehensive scale that incorporates feedback from

226 the $C A B$ and has high validity and reliability. Thus, although we excluded 15 items from the

227 scale, these items could be included in surveys that are able to include a longer list of

228 questions. In addition, we included the question on coercion despite its poor performance in

229 factor analysis because of its importance to the experiences of women of color. The

230 performance of this item should be reassessed in future studies.

The PCMC-US scale is different from other scales for measuring birthing people's

232 experience. First, to our knowledge it is the first available, validated person-centered care scale 
medRxiv preprint doi: https://doi.org/10.1101/2021.05.06.21256758; this version posted May 10, 2021. The copyright holder for this preprint (which was not certified by peer review) is the author/funder, who has granted medRxiv a license to display the preprint in perpetuity.

It is made available under a CC-BY-NC 4.0 International license.

233 that centers the childbirth experiences of Black birthing people. Continuous engagement with

234 members of the priority community ensured that the items in the scale capture their unique

235 experiences (Altman et al., 2019, 2020; McLemore et al., 2018). The scale items were

236 intentionally developed to include a mix of subjective questions to capture people's subjective

237 perceptions as well as more objective and actionable items that can inform quality

238 improvement (Afulani, Aborigo, et al., 2019; Montagu et al., 2020). The PCMC-US scale is also

239 among the few tools that measure experiences of person-centered care during childbirth in a

240 comprehensive manner (Nilvér et al., 2017).

241 Strengths and Limitations

242 A key strength of this study is the use of a community-based participatory approach embedded

243 in standard instrument development methods. This helped ensure that the PCMC-US scale is

244 relevant to people of color-particularly the Black community. Starting with a validated tool

245 also provided a rigorous, theory-based foundation for the adaptation. A potential limitation is

246 generalizability, given the relatively highly educated validation sample. This, however, is also a

247 strength of the study, as it represents the views of a diverse group of Black people. Another

248 limitation is the low representation of non-Black persons of color, which is likely because the

249 survey was only administered in English. Plans for validation in a Spanish-speaking population

250 are in place. The similarities between the original PCMC scale and the US version suggests that

251 the scale may be applicable across different populations. Validations in new populations are

252 however needed. Respondent burden due to the length of the scale may be a limitation.

253 However, given the multidimensional nature of person-centered maternity care, the

254 assessment of the relevance of the items included, and their psychometric performance, this is 
medRxiv preprint doi: https://doi.org/10.1101/2021.05.06.21256758; this version posted May 10, 2021. The copyright holder for this preprint (which was not certified by peer review) is the author/funder, who has granted medRxiv a license to display the preprint in perpetuity.

It is made available under a CC-BY-NC 4.0 International license .

255 the most parsimonious version of the scale we are able to recommend at this time. The sub-

256 scales can be used individually where necessary, but we recommend measuring all three

257 domains to assess PCMC in a holistic manner: It takes about 10 minutes to answer all the

258 questions. Shorter versions will be developed in future studies when data from more diverse

259 samples are available, as was done for the low resource setting version (Afulani, Feeser, et al.,

260 2019).

261

262 Implications for Practice and/or Policy

263 Given the increasing documentation of the poor experience of people of color in health care

264 settings, it is important that these experiences are documented in a systematic manner. In

265 addition, there is the need to develop and evaluate interventions to improve the experiences of

266 people of color in health care settings including during childbirth. These efforts require

267 measures that center the experiences of the affected communities (K. Scott, 2019). The PCMC-

268 US scale, together with ongoing efforts to measure obstetric racism (K. A. Scott \& Davis, 2021),

269 provide tools for these purposes.

270

271

Conclusions

272 Using a community-engaged process, we adapted the PCMC scale that was initially developed

273 in Kenya and India to make it relevant to the experiences of people of color in the US. The

274 PCMC-US scale has high validity and reliability in a sample of predominantly black women. The

275 scale will help drive as well as serve as an accountability tool in efforts to reduce disparities in

276 pregnancy and birth outcomes. 
medRxiv preprint doi: https://doi.org/10.1101/2021.05.06.21256758; this version posted May 10, 2021. The copyright holder for this preprint

(which was not certified by peer review) is the author/funder, who has granted medRxiv a license to display the preprint in perpetuity.

It is made available under a CC-BY-NC 4.0 International license.

\section{REFERENCES}

Afifi, A. A., Clark, V., \& May, S. (2004). Principal components analysis: Chapter 14. In ComputerAided Multivariate Analysis (4th ed.). CRC Press.

Afulani, P. A., Aborigo, R. A., Walker, D., Moyer, C. A., Cohen, S., \& Williams, J. (2019). Can an integrated obstetric emergency simulation training improve respectful maternity care? Results from a pilot study in Ghana. Birth (Berkeley, Calif.). https://doi.org/10.1111/birt.12418

Afulani, P. A., Altman, M. R., Castillo, E., Bernal, N., Jones, L., Camara, T., Carrasco, Z., Williams, S., Sudhinaraset, M., \& Kuppermann, M. (2021). Development of the Person-Centered Prenatal Care scale for People of Color. American Journal of Obstetrics \& Gynecology, O(0). https://doi.org/10.1016/j.ajog.2021.04.216

Afulani, P. A., Diamond-Smith, N., Golub, G., \& Sudhinaraset, M. (2017). Development of a tool to measure person-centered maternity care in developing settings: Validation in a rural and urban Kenyan population. Reproductive Health, 14. https://doi.org/10.1186/s12978-017-0381-7

Afulani, P. A., Diamond-Smith, N., Phillips, B., Singhal, S., \& Sudhinaraset, M. (2018). Validation of the person-centered maternity care scale in India. Reproductive Health, 15(1), 147. https://doi.org/10.1186/s12978-018-0591-7

Afulani, P. A., Feeser, K., Sudhinaraset, M., Aborigo, R., Montagu, D., \& Chakraborty, N. (2019). Toward the development of a short multi-country person-centered maternity care scale. International Journal of Gynecology \& Obstetrics, $\mathrm{O}(0)$. https://doi.org/10.1002/ijgo.12827 
medRxiv preprint doi: https://doi.org/10.1101/2021.05.06.21256758; this version posted May 10, 2021. The copyright holder for this preprint (which was not certified by peer review) is the author/funder, who has granted medRxiv a license to display the preprint in perpetuity. It is made available under a CC-BY-NC 4.0 International license .

Afulani, P. A., Ogolla, B. A., Oboke, E. N., Ongeri, L., Weiss, S. J., Lyndon, A., \& Mendes, W. B. (2021). Understanding disparities in person-centred maternity care: The potential role of provider implicit and explicit bias. Health Policy and Planning, czaa190.

Afulani, P. A., Phillips, B., Aborigo, R. A., \& Moyer, C. A. (2019). Person-centred maternity care in low-income and middle-income countries: Analysis of data from Kenya, Ghana, and India. The Lancet. Global Health, 7(1), e96-e109. https://doi.org/10.1016/S2214$109 \times(18) 30403-0$

Alhusen, J. L., Bower, K. M., Epstein, E., \& Sharps, P. (2016). Racial Discrimination and Adverse Birth Outcomes: An Integrative Review. Journal of Midwifery \& Women's Health, 61(6), 707-720. https://doi.org/10.1111/jmwh.12490

Altman, M. R., McLemore, M. R., Oseguera, T., Lyndon, A., \& Franck, L. S. (2020). Listening to Women: Recommendations from Women of Color to Improve Experiences in Pregnancy and Birth Care. Journal of Midwifery \& Women's Health, $n / a(n / a)$. https://doi.org/10.1111/jmwh.13102

Altman, M. R., Oseguera, T., McLemore, M. R., Kantrowitz-Gordon, I., Franck, L. S., \& Lyndon, A. (2019). Information and power: Women of color's experiences interacting with health care providers in pregnancy and birth. Social Science \& Medicine, 238, 112491. https://doi.org/10.1016/j.socscimed.2019.112491

Collins, D. (2003). Pretesting survey instruments: An overview of cognitive methods. Quality of Life Research: An International Journal of Quality of Life Aspects of Treatment, Care and Rehabilitation, 12(3), 229-238. 
medRxiv preprint doi: https://doi.org/10.1101/2021.05.06.21256758; this version posted May 10, 2021. The copyright holder for this preprint (which was not certified by peer review) is the author/funder, who has granted medRxiv a license to display the preprint in perpetuity. It is made available under a CC-BY-NC 4.0 International license .

321 DeVellis, R. F. (2016). Scale Development: Theory and Applications (4 edition). SAGE

$322 \quad$ Publications, Inc.

323 Harris, P. A., Taylor, R., Thielke, R., Payne, J., Gonzalez, N., \& Conde, J. G. (2009). Research Informatics, 42(2), 377-381. https://doi.org/10.1016/j.jbi.2008.08.010

Hinkin, T., Tracey, J., \& Enz, C. (1997). Scale Construction: Developing Reliable and Valid Measurement Instruments. Articles and Chapters. http://scholarship.sha.cornell.edu/articles/613

Holbrook, A. (2008). Acquiescence Response Bias. In P. Lavrakas, Encyclopedia of Survey Research Methods. Sage Publications, Inc. https://doi.org/10.4135/9781412963947.n3 Quality Chasm: A New Health System for the 21st Century. National Academies Press (US). http://www.ncbi.nlm.nih.gov/books/NBK222274/ Women's Perspectives on the Meaning of Safety During Hospital-Based Birth. Journal of Obstetric, Gynecologic, and Neonatal Nursing: JOGNN, 47(3), 324-332. care experiences of pregnant, birthing and postnatal women of color at risk for preterm birth. Social Science \& Medicine (1982), 201, 127-135. https://doi.org/10.1016/j.socscimed.2018.02.013 
medRxiv preprint doi: https://doi.org/10.1101/2021.05.06.21256758; this version posted May 10, 2021. The copyright holder for this preprint (which was not certified by peer review) is the author/funder, who has granted medRxiv a license to display the preprint in perpetuity. It is made available under a CC-BY-NC 4.0 International license .

343 Montagu, D., Giessler, K., Nakphong, M. K., Roy, K. P., Sahu, A. B., Sharma, K., Green, C., \& Sudhinaraset, M. (2020). Results of a person-centered maternal health quality improvement intervention in Uttar Pradesh, India. PLOS ONE, 15(12), e0242909. https://doi.org/10.1371/journal.pone.0242909

Nápoles-Springer, A. M., Santoyo-Olsson, J., O’Brien, H., \& Stewart, A. L. (2006). Using cognitive interviews to develop surveys in diverse populations. Medical Care, 44(11 Suppl 3), S2130. https://doi.org/10.1097/01.mlr.0000245425.65905.1d

Nilvér, H., Begley, C., \& Berg, M. (2017). Measuring women's childbirth experiences: A systematic review for identification and analysis of validated instruments. $B M C$ Pregnancy and Childbirth, 17(1), 203. https://doi.org/10.1186/s12884-017-1356-y

Scott, K. (2019). Redesigning Perinatal Quality Improvement: Community Driven Measures, Meanings, and Methods. Brooklyn Grows. https://www.brooklyngrows.com/blog/2019/11/3/redesigning-perinatal-qualityimprovement-community-driven-measures-meanings-and-methodsnbsp

357 Scott, K. A., \& Davis, D.-A. (2021). Obstetric Racism: Naming and Identifying a Way Out of Black Women's Adverse Medical Experiences. American Anthropologist, 00(00), 1-4.

Sheferaw, E. D., Mengesha, T. Z., \& Wase, S. B. (2016). Development of a tool to measure women's perception of respectful maternity care in public health facilities. BMC Pregnancy and Childbirth, 16, 67. https://doi.org/10.1186/s12884-016-0848-5

363 Tunçalp, ?.?., Were, W., MacLennan, C., Oladapo, O., Gülmezoglu, A., Bahl, R., Daelmans, B., 
medRxiv preprint doi: https://doi.org/10.1101/2021.05.06.21256758; this version posted May 10, 2021. The copyright holder for this preprint (which was not certified by peer review) is the author/funder, who has granted medRxiv a license to display the preprint in perpetuity. It is made available under a CC-BY-NC 4.0 International license .

for pregnant women and newborns-The WHO vision. BJOG: An International Journal of Obstetrics \& Gynaecology, 122(8), 1045-1049. https://doi.org/10.1111/14710528.13451

Vedam, S., Stoll, K., Martin, K., Rubashkin, N., Partridge, S., Thordarson, D., Jolicoeur, G., \& Changing Childbirth in BC Steering Council. (2017). The Mother's Autonomy in Decision Making (MADM) scale: Patient-led development and psychometric testing of a new instrument to evaluate experience of maternity care. PloS One, 12(2), e0171804.

Vedam, S., Stoll, K., McRae, D. N., Korchinski, M., Velasquez, R., Wang, J., Partridge, S., McRae, autonomy and respect in Canadian maternity care. Patient Education and Counseling,

Vedam, S., Stoll, K., Rubashkin, N., Martin, K., Miller-Vedam, Z., Hayes-Klein, H., \& Jolicoeur, G. (2017). The Mothers on Respect (MOR) index: Measuring quality, safety, and human rights in childbirth. SSM - Population Health, 3, 201-210.

381 Vedam, S., Stoll, K., Taiwo, T. K., Rubashkin, N., Cheyney, M., Strauss, N., McLemore, M., pregnancy and childbirth in the United States. Reproductive Health, 16(1), 77. 
medRxiv preprint doi: https://doi.org/10.1101/2021.05.06.21256758; this version posted May 10, 2021. The copyright holder for this preprint (which was not certified by peer review) is the author/funder, who has granted medRxiv a license to display the preprint in perpetuity. It is made available under a CC-BY-NC 4.0 International license .

386 WHO. (2016). Standards for improving quality of maternal and newborn care in health facilities.

387 http://www.who.int/maternal_child_adolescent/documents/improving-maternalnewborn-care-quality/en/

389

390 
Table 1: Person-Centered Maternity Care (PCMC) questions

No. Question in original PCMC scale

How did you feel about the amount of time you waited? Would you say it was

1. very short, somewhat short, somewhat long, or very long? 2

2.

During your time in the health facility did the doctors, nurses, or other health care

3. providers introduce themselves to you when they first came to see you?

Did the doctors, nurses, or other health

4. care providers call you by your name?

Did the doctors, nurses, or other staff at

5. the facility treat you with respect?

6.

7.

8.

9.

During examinations in the labor room, were you covered up with a cloth or

10. blanket or screened with a curtain so that you did not feel exposed?

Do you feel like your health information

11. was or will be kept confidential at this facility?

Did you feel like the doctors, nurses or

12. other staff at the facility involved you in decisions about your care?

13.

Did the doctors and nurses explain to you

14. why they were doing examinations or procedures on you?

15.

Did the doctors and nurses explain to you

16. why they were giving you any medicine?

Final question in PCMC-US scale ${ }^{1}$

Label

How did you feel about the amount of time you had to wait before being examined by a health care provider (doctor or midwife)?

How did you feel about the amount of time you had to wait in triage before being seen and assessed?

Did each new provider introduce themselves to you when they first came to see you?

Did your providers call you by your preferred name?

Did your providers treat you with respect?

Did you feel your experience and knowledge were valued?

Did you feel your customs and culture were respected by your providers?

Did you feel heard and listened to by your providers?

Did providers knock on your room's door and wait for response before entering?

During exams, were you covered up with a cloth or blanket or screened with a curtain so that you did not feel exposed?

Did you feel your health information was kept confidential and private by providers and staff?

Did your providers involve you in decisions about your care?

Did you feel coerced or pressured into a decision by providers?

Did your providers explain to you why they were doing examinations or procedures on you?

Did your providers explain to you why they were doing examinations or procedures on your baby?

Did your providers explain to you why they were giving you any medicine?
Wait time

Triage time

Introduction

Preferred name

Treated with

respect

Experience

valued

Customs

respected

Felt heard

Privacy-knock on door

Privacy-

covered

Information

confidential

Involved in

decisions

Coercion

Explain procedures

Explain baby procedures

Explain medication 
Did the doctors, nurses or other staff at the facility ask your permission/consent before doing procedures and examinations on you?

18.

During the delivery, do you feel like you

19. were able to be in the position of your choice?

Were you allowed to eat or drink when

20. you were hungry/thirsty?

Did the doctors, nurses or other staff at

21. the facility speak to you in a language you could understand?

22.

Did the doctors and nurses at the facility

23. talk to you about how you were feeling?

24.

Did you feel you could ask the doctors,

25. nurses or other staff at the facility any questions you had?

26.

27.

28.

29.

Did the doctors, nurses, and other staff at

30. the facility show they cared for you?

31.

Were you allowed to have someone you 32. wanted to stay with you during delivery?

When you needed help, did you feel the 33. doctors, nurses or other staff at the facility paid attention?

Did the doctors and nurses ask how much
Did providers or other staff ask your

Consent permission/consent before touching or doing procedures or examinations on you?

Did you feel your birth plan or preferences were respected? (i.e. moving during labor, pain management, music, birthing position)

Birth preferences respected

Were you able to give birth in the position of your choice?

Birth position of choice

Were you able to eat and drink if desired?

Eat

Did your providers speak to you using language or words you could understand?

Language understood

Did you feel informed about what was happening to you during your childbirth?

Did your providers ask about your emotional wellbeing?

Did your providers provide you with resources to help with your emotional well-being if you needed it?

Did you feel you could ask your providers any questions you had?

Did you hold back on asking questions for any reason?

Did providers encourage you to ask questions?

Did providers check that you understood information that was given to you?

Do you feel your questions were answered when you did ask?

Did providers give you information in a way that showed they cared about you?

Did providers respect your family or companions who were with you?

Were you allowed to have everyone you wanted (e.g. doula, elder, friends, or family) stay with you during your childbirth?

Did you feel your providers responded in a timely manner when you requested assistance?

Did you feel your providers believed you when you said you were in pain?
Felt informed

Emotional well-being

Resources for emotional wellbeing Could ask questions

Hold back on asking questions Encourage you to ask questions Checked understanding

Questions were answered

Information showed they cared Family respected

Companionship

Timely response

Believed about pain 
35. Do you feel the doctors or nurses did everything they could to help control your pain?

36.

Did you feel the doctors, nurses, or other

37. health providers shouted at you, scolded,

insulted, threatened, or talked to you rudely?

Did you feel like you were treated

38. roughly like pushed, beaten, slapped, pinched, physically restrained, or gagged?

Did you feel the doctors, nurses or other

39. staff at the facility took the best care of you?

Did you feel you could completely trust

40. the doctors, nurses or other staff at the

facility with regards to your care?

During your time in the health facility,

would you say you were treated differently because of any personal

41. attribute... like your age, marital status, number of children, your education, wealth, your connections with the facility, or something like that? ${ }^{3}$

42.

43.

44.

45.

46.

Thinking about the wards, washrooms

47.

and the general environment of the health

facility, will you say the facility was very

clean, clean, dirty, or very dirty?

Thinking about the labor and postnatal

48. wards, Did you feel the health facility was crowded?

49.

In general, did you feel safe in the health facility?
Do you feel your providers did everything they could to help you manage your pain?

Did you feel your providers avoided, ignored, or otherwise neglected you?

Did you feel your providers shouted at you, scolded, insulted, threatened, or talked to you rudely?

Did you feel like your providers handled you roughly, held you down, or physically restrained you?

Did you feel your providers took the best care of you?

Did you feel you could completely trust your providers with regards to your care?

Would you say you were discriminated against because of your race, ethnicity, culture, sex, gender, sexual orientation, language, immigration status, religion, income, education, age, marital status, number of children, insurance status, or other attribute?

Were you separated from your baby at any time after the birth?

Was your feeding choice for your baby

(breastfeeding, bottle feeding, both) respected by providers?

Did you receive the support you needed to reach your baby's feeding goals? (i.e. lactation support)

Were you supported in creating a birth environment that made you feel comfortable?

Do you think the place you gave birth met your needs?

Thinking about the place where you gave birth, did you feel that the rooms and facilities were clean?

Did you feel the place you gave birth was crowded during your birth stay? (i.e. not enough beds, moved from room to room, being in triage a long time)

In general, did you feel physically safe in or around your place of birth?

Did you feel you had access to your preferred place of birth?
Pain

management

Neglected

Verbal abuse

Physical abuse

Took best care

Trust

Discrimination

Separated from

baby

Baby feeding

choice

respected

Support for

baby feeding

Comfortable

birth

environment

Needs met

Clean rooms

Crowded

Felt safe

Preferred clinic 
medRxiv preprint doi: https://doi.org/10.1101/2021.05.06.21256758; this version posted May 10, 2021. The copyright holder for this preprint (which was not certified by peer review) is the author/funder, who has granted medRxiv a license to display the preprint in perpetuity.

It is made available under a CC-BY-NC 4.0 International license.

Notes:

${ }^{1}$ All questions have responses options 0 . No, never; 1. Yes, a few times; 2. Yes, most of the time; 3 . Yes, all the time. Except the following:

Wait time and triage time options: 0 . It was just right; 1 .It was somewhat long; 2 . It was very long; 3 . It was extremely long

Introduction options: 0 . No, none of them; 1 . Yes, a few of them; 2. Yes, most of them; 3. Yes, all of them

Neglect, verbal, and physical abuse options: 0 . No, never; 1 . Yes, once; 2. Yes, a few times; 3 . Yes, many times

${ }^{2}$ Blank implies not part of original scale and added as part of adaptation process.

${ }^{3}$ Fell out after factor analysis of original scale.

${ }^{4}$ Questions in original PCMC scale excluded from PCMC-US scale include:

Was there water in the facility?

Was there electricity in the facility?

Did the doctors, nurses, and other staff at the facility treat you in a friendly manner?

Did the doctors, nurses or other staff at the facility support your anxieties and fears?

Do you think there was enough health staff in the facility to care for you?

"Were you allowed to have someone you wanted to stay with you during labor?" and "[w]ere you allowed to have someone you wanted to stay with you during the delivery?" were combined into one question 
medRxiv preprint doi: https://doi.org/10.1101/2021.05.06.21256758; this version posted May 10, 2021. The copyright holder for this preprint (which was not certified by peer review) is the author/funder, who has granted medRxiv a license to display the preprint in perpetuity.

It is made available under a CC-BY-NC 4.0 International license .

Table 2: Characteristics of respondents $(\mathrm{N}=297)$

\begin{tabular}{|c|c|c|}
\hline & No. & $\%$ \\
\hline \multicolumn{3}{|l|}{ Race/ethnicity } \\
\hline Black/African American & 242 & 81.5 \\
\hline White/Caucasian & 33 & 11.1 \\
\hline Asian & 5 & 1.7 \\
\hline Hawaiian/Pacific Islander & 3 & 1.0 \\
\hline Latina/Hispanic & 18 & 6.1 \\
\hline American Indian/Alaskan Native & 3 & 1.0 \\
\hline Multiracial & 2 & 0.7 \\
\hline Other & 5 & 1.7 \\
\hline Prefer not to answer & 3 & 1.0 \\
\hline \multicolumn{3}{|l|}{ Partner's race/ethnicity } \\
\hline Black/African American & 240 & 80.8 \\
\hline White/Caucasian & 35 & 11.8 \\
\hline Asian & 4 & 1.3 \\
\hline Hawaiian/Pacific Islander & 1 & 0.3 \\
\hline Latinx/Hispanic & 18 & 6.1 \\
\hline American Indian/Alaskan Native & 2 & 0.7 \\
\hline Multiracial & 1 & 0.3 \\
\hline Other & 3 & 1.0 \\
\hline Prefer not to answer & 2 & 0.7 \\
\hline No partner & 2 & 0.7 \\
\hline \multicolumn{3}{|l|}{ Age } \\
\hline $17-28$ & 102 & 34.3 \\
\hline $29-32$ & 125 & 42.1 \\
\hline $33-45$ & 70 & 23.6 \\
\hline Married & 263 & 88.6 \\
\hline Primiparous & 225 & 75.8 \\
\hline \multicolumn{3}{|l|}{ Time since delivery } \\
\hline$<3$ months & 103 & 34.7 \\
\hline 3-4 months & 106 & 35.7 \\
\hline 5-12 months & 88 & 29.6 \\
\hline \multicolumn{3}{|l|}{ Educational attainment } \\
\hline High school or less & 38 & 12.8 \\
\hline Some college & 106 & 35.7 \\
\hline College graduate & 153 & 51.5 \\
\hline \multicolumn{3}{|l|}{ Average yearly income } \\
\hline$<\$ 50,000$ & 62 & 20.9 \\
\hline$\$ 50,0001-\$ 100,000$ & 185 & 62.3 \\
\hline$>\$ 100,000$ & 50 & 16.8 \\
\hline \multicolumn{3}{|l|}{ Employment status } \\
\hline Not employed & 104 & 35.0 \\
\hline Employed full-time & 152 & 51.2 \\
\hline Employed part-time & 37 & 12.5 \\
\hline Prefer not to answer & 4 & 1.3 \\
\hline \multicolumn{3}{|l|}{ Insurance type } \\
\hline No insurance & 7 & 2.4 \\
\hline Private/employer-provided insurance & 243 & 81.8 \\
\hline Medicaid/MediCal & 16 & 5.4 \\
\hline Medicare & 22 & 7.4 \\
\hline Tricare/government & 2 & 0.7 \\
\hline Prefer not to answer & 7 & 2.4 \\
\hline
\end{tabular}


Table 3: Results of exploratory factor analysis for 35-item Person-Centered Maternity Care - US scale (N=297)

\begin{tabular}{|c|c|c|c|c|c|c|c|c|c|c|}
\hline & \multicolumn{2}{|c|}{ Single factor } & \multicolumn{4}{|c|}{ Three factor structure } & \multicolumn{4}{|c|}{ L Loading on individual sub-scales } \\
\hline & F1 & Uniqueness & $\mathrm{F} 1$ & $\mathrm{~F} 2$ & F3 & Uniqueness & $\mathrm{CA}$ & DR & $\mathrm{RS}$ & Uniqueness \\
\hline 1. Introduction & 0.36 & 0.87 & & 0.23 & & 0.86 & 0.36 & & & 0.87 \\
\hline 2. Felt heard & 0.72 & 0.49 & 0.33 & 0.47 & & 0.47 & 0.75 & & & 0.44 \\
\hline 3. Involved in decisions & 0.77 & 0.41 & 0.45 & 0.42 & & 0.39 & 0.79 & & & 0.37 \\
\hline 4. Explain procedures & 0.68 & 0.54 & & 0.59 & & 0.47 & 0.72 & & & 0.49 \\
\hline 5. Consent & 0.59 & 0.66 & & 0.69 & & 0.55 & 0.62 & & & 0.62 \\
\hline 6. Language understood & 0.40 & 0.84 & 0.28 & & & 0.82 & 0.48 & & & 0.77 \\
\hline 7. Felt informed & 0.55 & 0.70 & & 0.44 & & 0.68 & 0.60 & & & 0.64 \\
\hline 8. Could ask questions & 0.63 & 0.61 & & 0.42 & & 0.57 & 0.64 & & & 0.59 \\
\hline 9. Checked understanding & 0.71 & 0.49 & 0.57 & & & 0.44 & 0.72 & & & 0.48 \\
\hline 10. Birth position of choice & 0.53 & 0.72 & 0.44 & & & 0.67 & 0.48 & & & 0.77 \\
\hline 11. Explain baby procedures & 0.63 & 0.60 & 0.30 & 0.41 & & 0.58 & 0.70 & & & 0.51 \\
\hline 12. Birth preferences respected & 0.52 & 0.73 & 0.36 & & & 0.72 & 0.54 & & & 0.71 \\
\hline 13. Baby feeding choice respected & 0.58 & 0.66 & & 0.32 & & 0.66 & 0.56 & & & 0.69 \\
\hline 14. Coercion & 0.13 & 0.98 & & & 0.47 & 0.78 & 0.10 & & & 0.99 \\
\hline 15. Treated with respect & 0.76 & 0.42 & & 0.63 & & 0.38 & & 0.75 & & 0.44 \\
\hline 16. Family respected & 0.79 & 0.38 & 0.70 & & & 0.33 & & 0.80 & & 0.36 \\
\hline 17. Information confidential & 0.50 & 0.75 & & 0.81 & & 0.54 & & 0.43 & & 0.81 \\
\hline 18. Privacy-covered & 0.46 & 0.79 & & 0.41 & & 0.71 & & 0.44 & & 0.80 \\
\hline 19. Verbal abuse & 0.52 & 0.73 & 0.55 & & 0.32 & 0.60 & & 0.54 & & 0.71 \\
\hline 20. Physical abuse & 0.54 & 0.71 & 0.56 & & & 0.66 & & 0.56 & & 0.69 \\
\hline 21. Discrimination & 0.74 & 0.45 & 0.74 & & & 0.37 & & 0.81 & & 0.34 \\
\hline 22. Neglected & 0.61 & 0.63 & 0.59 & & 0.35 & 0.49 & & 0.62 & & 0.61 \\
\hline 23. Experience valued & 0.78 & 0.39 & 0.40 & 0.47 & & 0.37 & & 0.73 & & 0.47 \\
\hline 24. Customs respected & 0.60 & 0.64 & 0.71 & & & 0.53 & & 0.63 & & 0.60 \\
\hline 25. Emotional well-being & 0.56 & 0.69 & 0.52 & & & 0.61 & & & 0.52 & 0.73 \\
\hline 26. Pain management & 0.45 & 0.80 & & 0.32 & & 0.77 & & & 0.47 & 0.78 \\
\hline 27. Took best care & 0.73 & 0.46 & & 0.58 & 0.37 & 0.35 & & & 0.79 & 0.38 \\
\hline 28. Trust & 0.73 & 0.46 & & 0.75 & & 0.33 & & & 0.78 & 0.40 \\
\hline 29. Felt safe & 0.58 & 0.66 & & 0.54 & 0.34 & 0.55 & & & 0.59 & 0.65 \\
\hline 30. Companionship & 0.51 & 0.74 & 0.68 & & & 0.63 & & & 0.52 & 0.73 \\
\hline 31. Timely response & 0.62 & 0.62 & 0.54 & & & 0.58 & & & 0.65 & 0.58 \\
\hline 32. Believed about pain & 0.63 & 0.60 & 0.49 & & & 0.58 & & & 0.66 & 0.56 \\
\hline 33. Support for baby feeding & 0.52 & 0.73 & & 0.46 & & 0.70 & & & 0.49 & 0.76 \\
\hline 34. Comfortable birth environment & 0.75 & 0.43 & 0.72 & & & 0.38 & & & 0.73 & 0.47 \\
\hline 35. Wait time & 0.50 & 0.75 & 0.35 & & & 0.73 & & & 0.50 & 0.75 \\
\hline
\end{tabular}


Table 4: Scale and sub-scale properties and distribution of scores $(\mathrm{N}=297)$

\begin{tabular}{|c|c|c|c|c|c|c|c|c|c|c|}
\hline \multirow[b]{3}{*}{ Full PCMC-US scale } & \multirow[b]{2}{*}{ No. of items } & \multirow[b]{2}{*}{ Cronbach's alpha } & \multicolumn{4}{|c|}{ Raw scores } & \multicolumn{4}{|c|}{ Standardized score } \\
\hline & & & Mean & SD & Min & Max & Mean & SD & Min & Max \\
\hline & 35 & 0.95 & 93.6 & 12.9 & 22.0 & 105.0 & 89.2 & 12.3 & 21.0 & 100.0 \\
\hline $\begin{array}{l}\text { Communication \& } \\
\text { autonomy }\end{array}$ & 14 & 0.87 & 37.1 & 5.2 & 11.0 & 42.0 & 88.4 & 12.3 & 26.2 & 100.0 \\
\hline Dignity \& respect & 10 & 0.87 & 27.7 & 3.6 & 7.0 & 30.0 & 92.4 & 12.1 & 23.3 & 100.0 \\
\hline $\begin{array}{l}\text { Responsive \& supportive } \\
\text { care }\end{array}$ & 11 & 0.87 & 28.8 & 4.8 & 4.0 & 33.0 & 87.2 & 14.6 & 12.1 & 100.0 \\
\hline
\end{tabular}

Table 5: Bivariate logistic and linear regression of scale scores on related measures to assess criterion validity $(\mathrm{N}=297)$

\begin{tabular}{|c|c|c|c|c|c|c|c|c|c|c|c|c|c|c|c|}
\hline \multirow[b]{3}{*}{ Full PCMC-US scale } & \multicolumn{3}{|c|}{ Satisfied with care } & \multicolumn{3}{|c|}{$\begin{array}{l}\text { Will birth in same } \\
\text { place again }\end{array}$} & \multicolumn{3}{|c|}{$\begin{array}{c}\text { Rated quality of care } \\
\text { as very good }\end{array}$} & \multicolumn{3}{|c|}{ MADM score } & \multicolumn{3}{|c|}{ MORi score } \\
\hline & \multirow{2}{*}{$\begin{array}{l}O R \\
1.14 * * *\end{array}$} & \multicolumn{2}{|c|}{$95 \% C I$} & \multirow{2}{*}{$\begin{array}{l}O R \\
1.09 * * *\end{array}$} & \multicolumn{2}{|c|}{$95 \% C I$} & \multirow{2}{*}{$\begin{array}{l}O R \\
1.11 * * *\end{array}$} & \multicolumn{2}{|c|}{$95 \% C I$} & \multirow{2}{*}{$\begin{array}{l}\beta \\
0.35 * * *\end{array}$} & \multicolumn{2}{|c|}{$95 \% C I$} & \multirow{2}{*}{$\begin{array}{l}\beta \\
0.20 * * *\end{array}$} & \multicolumn{2}{|c|}{$95 \% C I$} \\
\hline & & {$[1.09$} & 1.18] & & {$[1.06$} & $1.11]$ & & {$[1.07$} & $1.14]$ & & {$[0.32$} & $0.39]$ & & {$[0.17$} & $0.22]$ \\
\hline $\begin{array}{l}\text { Communication \& } \\
\text { autonomy }\end{array}$ & $1.13 * * *$ & {$[1.09$} & 1.17] & $1.08 * * *$ & {$[1.05$} & $1.11]$ & $1.10 * * *$ & {$[1.07$} & $1.13]$ & $0.34 * * *$ & {$[0.30$} & $0.38]$ & $0.18 * * *$ & {$[0.15$} & $0.21]$ \\
\hline Dignity \& respect & $1.10 * * *$ & {$[1.07$} & $1.14]$ & $1.07 * * *$ & {$[1.04$} & $1.09]$ & $1.10 * * *$ & {$[1.06$} & $1.13]$ & $0.33 * * *$ & {$[0.28$} & $0.37]$ & $0.20 * * *$ & {$[0.17$} & $0.23]$ \\
\hline $\begin{array}{l}\text { Responsive \& } \\
\text { supportive care }\end{array}$ & $1.13 * * *$ & {$[1.09$} & 1.17] & $1.08 * * *$ & {$[1.05$} & $1.10]$ & $1.09 * * *$ & {$[1.06$} & $1.12]$ & $0.28 * * *$ & {$[0.25$} & $0.32]$ & $0.16^{* * *}$ & {$[0.13$} & $0.18]$ \\
\hline
\end{tabular}

index. N=296 for MADM model; 


\section{Appendix A: Distribution of Individual PCMC-US Items (N=297)}

How did you feel about the amount of time you had to wait before being examined by a health care provider (doctor or midwife)?

0 . It was just right

$178 \quad 59.9$

1. It was somewhat long

$104 \quad 35$

2. It was very long

3. It was extremely long

$11 \quad 3.7$

Total

$4 \quad 1.3$

How did you feel about the amount of time you had to wait in triage before being

seen and assessed?

0 . It was just right

$205 \quad 69$

1. It was somewhat long

2. It was very long

3. It was extremely long

4. Not applicable (there was no triage)

$68 \quad 22.9$

93

$\begin{array}{ll}7 & 2.4\end{array}$

Total

Did each new provider introduce themselves to you when they first came to see

you? (If you were seen by only one provider and they introduced themselves, you can select yes, all of them.)

0 . No, none of them

$3 \quad 1$

1. Yes, a few of them

2. Yes, most of them

3. Yes, all of them

Total

Did your providers call you by your preferred name?

0 . No, never

1. Yes, a few times

2. Yes, most of the time

3. Yes, all the time

Total

Did your providers treat you with respect?

0 . No, never

1. Yes, a few times

2. Yes, most of the time

3. Yes, all the time

Total

Did you feel your experience and knowledge were valued?

0 . No, never

1. Yes, a few times

2. Yes, most of the time

3. Yes, all the time

Total

Did you feel your customs and culture were respected by your providers?

0 . No, never

1. Yes, a few times

62

2. Yes, most of the time

$\begin{array}{ll}7 & 2.4\end{array}$

3. Yes, all the time

4. I have no particular customs

Total

Did you feel heard and listened to by your providers?

0 . No, never

1. Yes, a few times

2. Yes, most of the time

3. Yes, all the time

$81 \quad 27.3$

$189 \quad 63.6$


Total

Did providers knock on your rooms door and wait for response before entering?

0. No, never

1. Yes, a few times

$15 \quad 5.1$

2. Yes, most of the time

$35 \quad 11.8$

3. Yes, all the time

$237 \quad 79.8$

4. Not applicable

$4 \quad 1.3$

Total

During exams, were you covered up with a cloth or blanket or screened with a curtain so that you did not feel exposed?

0 No, never

1 Yes, a few times

2 Yes, most of the time

$\begin{array}{cc}9 & 3 \\ 34 & 11.4 \\ 241 & 81.1 \\ 7 & 2.4 \\ 297 & 100\end{array}$

4 Not applicable

Did you feel your health information was kept confidential and private by providers and staff?

1. Yes, a few times

2. Yes, most of the time

$5 \quad 1.7$

3. Yes, all the time

Total

Did your providers involve you in decisions about your care?

0 . No, never

1. Yes, a few times

$1 \quad 0.3$

2. Yes, most of the time

$16 \quad 5.4$

3. Yes, all the time

Total

Did your providers explain to you why they were doing examinations or procedures

on you?

0 . No, never

1. Yes, a few times

$\begin{array}{ll}1 & 0.3\end{array}$

2. Yes, most of the time

$10 \quad 3.4$

3. Yes, all the time

$66 \quad 22.2$

Total

$220 \quad 74.1$

Did your providers explain to you why they were doing examinations or procedures

on your baby?

0 . No, never

1. Yes, a few times

2. Yes, most of the time

3. Yes, all the time

4. Not applicable / I was not present to be informed

Total

Did your providers explain to you why they were giving you any medicine?

0 . No, never

1. Yes, a few times

2. Yes, most of the time

3. Yes, all the time

4. Not applicable / I did not get any medicine

Total

$\begin{array}{cc}1 & 0.3 \\ 8 & 2.7 \\ 33 & 11.1 \\ 242 & 81.5 \\ 13 & 4.4 \\ 297 & 100 \\ & \\ 10 & 3.4 \\ 12 & 4 \\ 29 & 9.8 \\ 74 & 24.9 \\ 172 & 57.9 \\ 297 & 100 \\ & \\ & \\ 1 & 0.3 \\ 10 & 3.4 \\ 84 & 28.3\end{array}$


3. Yes, all the time

Total

Did you feel coerced or pressured into a decision by providers?

0 . No, never

1. Yes, a few times

$207 \quad 69.7$

2. Yes, most of the time

$50 \quad 16.8$

3. Yes, all the time

93

Total

Did you feel your birth plan or preferences were respected? (i.e. moving during

labor, pain management, music, birthing position)?

0 . No, never

1. Yes, a few times

2. Yes, most of the time

3. Yes, all the time

4. Not applicable

Total

Were you able to give birth in the position of your choice?

0 . No

1. Yes

2. Not applicable, I had a cesarean

Total

Were you able to eat and drink if desired?

0 . No, never

1. Yes, a few times

$6 \quad 2$

2. Yes, most of the time

3. Yes, all the time

4. It was not appropriate to eat (e.g. because of surgery)

Total

Did your providers speak to you using language or words you could understand?

0 . No, never

1. Yes, a few times

$297 \quad 100$

2. Yes, most of the time

$3 \quad 1$

3. Yes, all the time

Total

Did they provide an interpreter?

0 . No, never

1. Yes, a few times

2. Yes, most of the time

3. Yes, all the time

4. Not applicable

Total

Did you feel informed about what was happening to you during your childbirth?

0 . No, never

1. Yes, a few times

2. Yes, most of the time

3. Yes, all the time

Total

Did your providers ask about your emotional well-being?

0 . No, never

1. Yes, a few times

7.7

2. Yes, most of the time

7.4

3. Yes, all the time

Total

Did your providers provide you with resources to help with your emotional well- 
0. No, never

1. Yes, a few times

4.4

2. Yes, most of the time

$14 \quad 4.7$

3. Yes, all the time

$24 \quad 8.1$

4. Not applicable

$224 \quad 75.4$

Total

$22 \quad 7.4$

Did you feel you could ask your providers any questions you had?

0 . No, never

1. Yes, a few times

$4 \quad 1.3$

2. Yes, most of the time

$27 \quad 9.1$

3. Yes, all the time

Total

Did providers encourage you to ask questions?

0 . No, never

1. Yes, a few times

$10 \quad 3.4$

2. Yes, most of the time

5.1

3. Yes, all the time

Total

Did providers check that you understood information that was given to you?

0 . No, never

$5 \quad 1.7$

1. Yes, a few times

$10 \quad 3.4$

2. Yes, most of the time

$79 \quad 26.6$

3. Yes, all the time

Total

Did you hold back on asking questions for any reason?

0 . No, never

1. Yes, a few times

2. Yes, most of the time

3. Yes, all the time

$14 \quad 4.7$

Total

Do you feel your questions were answered when you did ask?

$297 \quad 100$

0 . No, never

1. Yes, a few times

$18 \quad 6.1$

2. Yes, most of the time

$35 \quad 11.8$

3. Yes, all the time

4. Not applicable / I did not have any questions

Total

$\begin{array}{cc}2 & 0.7 \\ 297 & 100\end{array}$

Did providers give you information in a way that showed they cared about you?

0 . No, never

1. Yes, a few times

$4 \quad 1.4$

2. Yes, most of the time

3. Yes, all the time

Total

Did providers respect your family or companions who were with you?

0 . No, never

1. Yes, a few times

2. Yes, most of the time

$1 \quad 0.3$

3. Yes, all the time

4. Not applicable

Total

$4 \quad 1.3$

Were you allowed to have everyone you wanted (e.g. doula, elder, friends, or family) stay with you during your childbirth?

0 . No, never

1. Yes, a few times

$7 \quad 2.4$

2. Yes, most of the time 
3. Yes, all the time

$\begin{array}{cc}244 & 82.2 \\ 2 & 0.7 \\ 297 & 100\end{array}$

Total

Did you feel your providers responded in a timely manner when you requested assistance?

0 . No, never

1. Yes, a few times

$\begin{array}{ll}2 & 0.7\end{array}$

2. Yes, most of the time

$14 \quad 4.7$

3. Yes, all the time

$48 \quad 16.2$

4. I did not request assistance

$224 \quad 75.4$

Total

$9 \quad 3$

Did you feel your providers believed you when you said you were in pain?

0 . No, never

1. Yes, a few times

2. Yes, most of the time

2. Yes, most of the time

Yes, all the time

4. Not applicable

Total

Do you feel your providers did everything they could to help you manage your

pain?

0 . No, never

1. Yes, a few times

2. Yes, most of the time

3. Yes, all the time

Total

Did you feel your providers avoided, ignored, or otherwise neglected you?

0 . No, never

1. Yes, once

2. Yes, a few times

6.7

3. Yes, many times

Total

Did you feel your providers shouted at you, scolded, insulted, threatened, or talked

1. Yes, once

2. Yes, a few times

3. Yes, many times

Total

Did you feel like your providers handled you roughly, held you down, or physically restrained you?

0 . No, never

1. Yes, once

2. Yes, a few times

3. Yes, many times

93

Total

$4 \quad 1.3$

Did you feel your providers took the best care of you?

$297 \quad 100$

0 . No, never

1. Yes, a few times

2. Yes, most of the time

3. Yes, all the time

Did you feel you could completely trust your providers with regards to your care?

0 . No, never

1. Yes, a few times

2. Yes, most of the time 
Would you say you were discriminated against because of your race, ethnicity, culture, sex, gender, sexual orientation, language, immigration status, religion, income, education, age, marital status, number of children, insurance status, or other attribute?

0. No, never

1. Yes, a few times

$10 \quad 3.4$

2. Yes, most of the time

62

3. Yes, all the time

10.3

Total

Were you separated from your baby at any time after the birth?

0 . No

1. Yes

2. Not sure/don't remember

10.3

Total

$297 \quad 100$

If you were separated from your baby, was it communicated to you as to why? 0 . No

1. Yes

Total

Was your feeding choice for your baby (breastfeeding, bottle feeding, both) respected by your providers?

0 . No, never

1. Yes, a few times

2. Yes, most of the time

$10 \quad 3.4$

3. Yes, all the time

4. Not applicable

Total

$4 \quad 1.3$

Did you receive the support you needed to reach your baby's feeding goals? (i.e.

Lactation support)?

0 . No, never

1. Yes, a few times

2. Yes, most of the time

3. Yes, all the time

4. Not applicable

Total

$1 \quad 0.3$

Were you supported in creating a birth environment that made you feel

$297 \quad 100$

comfortable?

0 . No, never

1. Yes, a few times

$3 \quad 1$

2. Yes, most of the time

$16 \quad 5.4$

3. Yes, all the time

$21 \quad 7.1$

4. Not applicable

Total

Thinking about the place where you gave birth, did you feel that the rooms and

facilities were clean?

0 . No, never

1. Yes, a few times

2. Yes, most of the time

$39 \quad 13.1$

3. Yes, all the time

4. Not applicable

$1 \quad 0.3$

Total

Did you feel the place you gave birth was crowded during your birth stay? (i.e. not enough beds, moved from room to room, being in triage a long time)?

0 . No, never 
medRxiv preprint doi: https://doi.org/10.1101/2021.05.06.21256758; this version posted May 10, 2021. The copyright holder for this preprint (which was not certified by peer review) is the author/funder, who has granted medRxiv a license to display the preprint in perpetuity.

It is made available under a CC-BY-NC 4.0 International license .

1. Yes, a few times

$39 \quad 13.1$

2. Yes, most of the time

$20 \quad 6.7$

3. Yes, all the time

$23 \quad 7.7$

4. Not applicable

10.3

Total

$297 \quad 100$

Did you feel you had access to your preferred place of birth?

0 . No

$14 \quad 4.8$

1. Yes

$279 \quad 95.2$

Total

Do you think the place you gave birth met your needs?

0 . No, never

62

1. Yes, a few times

$14 \quad 4.7$

2. Yes, most of the time

$75 \quad 25.3$

3. Yes, all the time

Total

In general, did you feel physically safe in or around your place of birth?

0 . No, never

$\begin{array}{ll}2 & 0.7\end{array}$

1. Yes, a few times

$6 \quad 2$

2. Yes, most of the time

$60 \quad 20.2$

3. Yes, all the time 


\section{Appendix B: Results from Survey to Prioritize Items (N=14)}

\begin{tabular}{|c|c|c|c|}
\hline No & Domain/Item & $\mathrm{N}$ & Notes \\
\hline & Communication and Autonomy & & \\
\hline 1 & $\begin{array}{l}\text { Did providers or other staff ask your permission/consent before } \\
\text { touching or doing procedures or examinations on you? }\end{array}$ & 14 & $\begin{array}{l}\text { High loading, High } \\
\text { priority: retained }\end{array}$ \\
\hline 2 & $\begin{array}{l}\text { Did your providers explain to you why they were doing examinations or } \\
\text { procedures on you? }\end{array}$ & 12 & $\begin{array}{l}\text { High loading, High } \\
\text { priority: retained }\end{array}$ \\
\hline 3 & $\begin{array}{l}\text { Did your providers explain to you why they were doing examinations or } \\
\text { procedures on your baby }\end{array}$ & 10 & $\begin{array}{l}\text { High loading, High } \\
\text { priority: retained }\end{array}$ \\
\hline 4 & Did your providers involve you in decisions about your care? & 10 & $\begin{array}{l}\text { High loading, High } \\
\text { priority: retained }\end{array}$ \\
\hline 5 & $\begin{array}{l}\text { Did you feel informed about what was happening to you during your } \\
\text { childbirth? }\end{array}$ & 10 & $\begin{array}{l}\text { High loading, High } \\
\text { priority: retained }\end{array}$ \\
\hline 6 & Did you feel coerced or pressured into a decision by providers? & 9 & $\begin{array}{l}\text { High loading, High } \\
\text { priority: retained }\end{array}$ \\
\hline 7 & Did you feel you could ask your providers any questions you had? & 8 & $\begin{array}{l}\text { High loading, High } \\
\text { priority: retained }\end{array}$ \\
\hline 8 & Did you feel heard and listened to by your providers? & 7 & $\begin{array}{l}\text { High loading, High } \\
\text { priority: retained }\end{array}$ \\
\hline 9 & $\begin{array}{l}\text { Did your providers speak to you using language or words you could } \\
\text { understand? }\end{array}$ & 7 & $\begin{array}{l}\text { High loading, High } \\
\text { priority: retained }\end{array}$ \\
\hline 10 & $\begin{array}{l}\text { Did each new provider introduce themselves to you when they first } \\
\text { came to see you? }\end{array}$ & 6 & $\begin{array}{l}\text { High loading, Moderate } \\
\text { priority: retained }\end{array}$ \\
\hline 11 & $\begin{array}{l}\text { Did providers check that you understood information that was given to } \\
\text { you? }\end{array}$ & 6 & $\begin{array}{l}\text { High loading, Moderate } \\
\text { priority: retained }\end{array}$ \\
\hline 12 & $\begin{array}{l}\text { Was your feeding choice for your baby (breastfeeding, bottle) respected } \\
\text { by providers? }\end{array}$ & 6 & $\begin{array}{l}\text { High loading, Moderate } \\
\text { priority: retained }\end{array}$ \\
\hline 13 & Did your providers call you by your preferred name? & 5 & $\begin{array}{l}\text { Low loading, Moderate } \\
\text { priority: removed }\end{array}$ \\
\hline 14 & $\begin{array}{l}\text { Did you feel your birth plan or preferences were respected? (i.e. moving } \\
\text { during labor, pain management, music, birthing position) }\end{array}$ & 5 & $\begin{array}{l}\text { High loading, Moderate } \\
\text { priority: retained }\end{array}$ \\
\hline 15 & Were you able to give birth in the position of your choice? & 5 & $\begin{array}{l}\text { High loading, Moderate } \\
\text { priority: retained }\end{array}$ \\
\hline 16 & Did your providers explain to you why they were giving medicine? & 4 & Low priority: removed \\
\hline 17 & Did you hold back on asking questions for any reason? & 3 & Low priority: removed \\
\hline 18 & Did providers encourage you to ask questions? & 3 & Low priority: removed \\
\hline 19 & $\begin{array}{l}\text { Do you feel your questions were answered when you did ask? } \\
\text { Dignity and Respect }\end{array}$ & 2 & Low priority: removed \\
\hline 1 & Did your providers treat you with respect? & 14 & $\begin{array}{l}\text { High loading, High } \\
\text { priority: retained }\end{array}$ \\
\hline 2 & Did providers respect your family or companions who were with you? & 14 & $\begin{array}{l}\text { High loading, High } \\
\text { priority: retained }\end{array}$ \\
\hline 3 & $\begin{array}{l}\text { Did you feel your providers shouted at you, scolded, insulted, } \\
\text { threatened, or talked to you rudely? }\end{array}$ & 13 & $\begin{array}{l}\text { High loading, High } \\
\text { priority: retained }\end{array}$ \\
\hline 4 & $\begin{array}{l}\text { Would you say you were discriminated against because of your race, } \\
\text { ethnicity, culture, sex, gender, sexual orientation, language, immigration } \\
\text { status, religion, income, education, age, marital status, number of } \\
\text { children, insurance status, or other attribute? }\end{array}$ & 13 & $\begin{array}{l}\text { High loading, High } \\
\text { priority: retained }\end{array}$ \\
\hline 5 & $\begin{array}{l}\text { Did you feel your providers avoided, ignored, or otherwise neglected } \\
\text { you? }\end{array}$ & 12 & $\begin{array}{l}\text { High loading, High } \\
\text { priority: retained }\end{array}$ \\
\hline 6 & $\begin{array}{l}\text { Did you feel your customs and culture were respected by your } \\
\text { providers? }\end{array}$ & 11 & $\begin{array}{l}\text { High loading, High } \\
\text { priority: retained }\end{array}$ \\
\hline 7 & $\begin{array}{l}\text { During exams, were you covered up with a cloth or blanket or screened } \\
\text { with a curtain so that you did not feel exposed? }\end{array}$ & 11 & $\begin{array}{l}\text { High loading, High } \\
\text { priority: retained }\end{array}$ \\
\hline 8 & $\begin{array}{l}\text { Did you feel like your providers handled you roughly, held you down, } \\
\text { or physically restrained you? }\end{array}$ & 8 & $\begin{array}{l}\text { High loading, High } \\
\text { priority: retained }\end{array}$ \\
\hline
\end{tabular}


9 Did you feel your experience and knowledge were valued?

10 Did you feel your health information was kept confidential and private by providers?

11 Did providers knock on your rooms door and wait for response before entering?

\section{Responsive and Supportive Care}

1 Did you feel you could completely trust your providers with regards to your care?

2 Did you feel your providers responded in a timely manner when you requested assistance?

3 Were you allowed to have everyone you wanted (e.g. doula, elder, friends, or family) stay with you during your childbirth?

4 Did your providers ask about your emotional well-being?

5 Do you feel your providers did everything they could to help you manage your pain?

6 In general, did you feel physically safe in or around your place of birth?

7 Did you feel your providers believed you when you said you were in pain?

8 Did you receive the support you needed to reach feeding goals? (i.e. Lactation support)

9 Were you supported in creating a birth environment that made you feel comfortable?

10 How did you feel about the amount of time you had to wait before being examined by a health care provider (doctor or midwife)?

11 Did you feel your providers took the best care of you?

12 Were you separated from your baby at any time after time after the birth?

13 How did you feel about the time you waited in triage before being seen and assessed?

14 Did providers give you information in a way that showed they cared about you?

15 Thinking about the place where you gave birth, did you feel that the rooms and facilities were clean?

16 Did you feel the place you gave birth was crowded during your birth stay? (i.e., not enough beds, moved from room to room, being in triage a long time)

17 Did your providers provide you with resources to help with your emotional well-being if you needed it?

18 Do you think the place you gave birth met your needs?

19 Were you able to eat and drink if desired?

20 Did you feel you had access to your preferred place of birth?
7 High loading, High priority: retained

5 High loading, moderate priority: retained

3 Low priority: removed

12 High loading, High priority: retained

11 High loading, High priority: retained

11 High loading, High priority: retained

11 High loading, High priority: retained

10 High loading, High priority: retained

10 High loading, High priority: retained

9 High loading, High priority: retained

8 High loading, High priority: retained

8 High loading, High priority: retained

7 High loading, High priority: retained

5 High loading, Moderate priority: retained

5 Low loading, Moderate priority: removed

4 Low priority: removed

4 Low priority: removed

$4 \quad$ Low priority: removed

4 Low priority: removed

3 Low priority: removed

3 Low priority: removed

2 Low priority: removed

2 Low priority: removed

Notes: Considered high priority if selected by at least half of respondents $(\mathrm{N}>7)$ and low priority if selected by a third of respondents $(<5)$. 